\title{
DISTRIBUTION AND PHENOTYPIC VARIABILITY ASPECTS OF SOME QUANTITATIVE TRAITS AMONG DURUM WHEAT ACCESSIONS
}

\author{
AYED SOUROUR and SLIM-AMARA HAJER \\ Genetic and Plant Breeding Laboratory, Department of Agronomy and Biotechnology. National Agronomic \\ Institute of Tunisia
}

Département d’Agronomie et Biotechnologie végétale. Institut National Agronomique de Tunisie. 43 Avenue Charles Nicolle 1082. Cité Mahrajene -Tunis, Tunisia

(Received 2 February, 2009; accepted 15 July, 2009)

\begin{abstract}
A durum wheat (Triticum durum Desf.) collection with 111 accessions represents a large part of the collection of Triticeae species in Tunisia were evaluated for six qualitative traits: seed colour, seed size, glume colour, glume pubescence, spike density and beak length. Distribution of traits showed that this germoplasm was dominated by dense spike, white and glabre glume, long beak, brown and large grain. Phenotypic diversity is determined by the index Shannon-Weaver $\left(\mathrm{H}^{\prime}\right)$. This index calculated for each parameter revealed that spike density $\left(\mathrm{H}^{\prime}=0.86\right)$, glume pubescence $\left(\mathrm{H}^{\prime}=0.80\right)$ and glume colour $\left(\mathrm{H}^{\prime}=0.79\right)$ showed the best diversity index. Seed size showed the weakest index $\left(\mathrm{H}^{\prime}=0.69\right)$ which indicated a low phenotypic variability for this parameter. This durum wheat germoplasm presented an average of diversity index about 0.77 , showing a large diversity of this collection. These values showed that the germoplasm has a relatively important diversity, confirming that Tunisia is one of the principal durum wheat secondary centres of diversification. This genetic diversity can be exploited in improvement programmes.
\end{abstract}

Key Words: Durum, glume pubescence, spike density, Triticum durum, Tunisia

\section{RÉSUMÉ}

Une collection de blé (Triticum durum Desf.) avec 111 nouvelles acquisitions représentant une grande partie de la collection des espèces Triticeae en Tunisie avaient été évalués pour six traits qualitatifs: couleur de semences, taille de semences, la couleur de glume, pubescence du glume, densité du pointe et longueur de bec. La distribution des traits avait montré que cette germoplasm avait été dominée par une dense pointe, glume blanc et glabre, long bec, grain brun et grande. La diversité phénotypique est déterminée par l'index de Shannon-Weaver (H'). Cet index calculé pour chaque paramètre a révélé que la densité du pointe $\left(\mathrm{H}^{\prime}=0,86\right)$, la pubescence du glume $\left(\mathrm{H}^{\prime}=\right.$ $0,80)$ et la couleur du glume $\left(\mathrm{H}^{\prime}=0,79\right)$ avait montré le meilleur indice de diversité. La taille de semences avait montré le plus faible index $\left(\mathrm{H}^{\prime}=0,69\right)$, ce qui avait indiqué une variabilité phénotypique faible pour ce paramètre. Cette germoplasm de blé dur a présenté une moyenne de l'index de diversité d'environ 0,77; montrant une grande diversité de cette collection. Ces valeurs ont montré que cette germoplasm a une diversité relativement importante, ce qui a confirmé que la Tunisie est l'un de principaux centres secondaire de diversification de blé dur. Cette diversité génétique peut être exploitée dans les programmes d’amélioration.

Mots Clés: Blé dur, de glume, pubescence densité du pointe, Triticum durum, Tunisie 


\section{INTRODUCTION}

Old cultivars of agricultural crops and local populations are attracting more and more attention from specialists in gene banks, breeding institutions, and research institutes holding and studying germplasm collections. Genetic variation in advanced cultivars is narrowing, and when desirable, gene donors are not found in collections of current cultivars, it is necessary to search for them among old materials and in wild relatives (Devra, 1999). Tunisia, like the other countries of the Mediterranean basin, is an area rich in crop biodiversity because it is characterised by a high diversity of climatic, edaphic and agronomic conditions.

Durum wheat is an important crop providing food and fodder in the world. Several studies on evaluation of indigenous durum wheat germoplasm on the agro-physiological level by quantitative parameters showed a significant richness of Tunisian germoplasm (Daaloul et al., 1998; Fakhfak et al., 1998; Khereddine et al., 1998). However, there are few reports on genetic variation of landraces of Tunisian durum wheat germoplasm at the morphological and qualitative traits level. The phenotypic diversity can be determined by the index of Shannon-Weaver (H') described by Hutcheson (1970). Similar studies were also made on the world collections of durum wheat landraces (Bechere, 1996; Jaradat, 1992), barley (Porfiri, 1992) and on Aegilops (Holubec, 1992). This work evaluated the phenotypic variability of 111 durum wheat autochton accessions by 6 qualitative parameters.

\section{MATERIALS AND METHODS}

A total of 111 accessions durum wheat (Triticum durum Desf.) were used for this study: Adjini (3 accessions), Agili (2 accessions), Hamira (3 accessions), Biskri (2 accessions), and Mahmoudi (2 accessions). Others included Media (3 accessions), Sbei (2 accessions), Derbassi (2 accessions), Jeneh Khotifa (3 accessions), Aoudj (1 accession), Bianculida (1 accession), and Bidi (1 accession). Also included were Mekki (1 accession), Real Sorte (1 accession), Souri (1 accession), Swabaa Elgia (1 accession), and Taganrog (1 accession).
All accessions were sown in fields at a seed rate of $120 \mathrm{~kg} \mathrm{ha}^{-1}$. These accessions were sown each one on 3 lines of $2 \mathrm{~m}$ and spacing of $18 \mathrm{~cm}$. At pre-sowing of phosphorus fertiliser (60 kg of $\mathrm{P}_{2} \mathrm{O}_{5}$ per hectare) was applied and post-sowing for nitrogen (100 kg of ammonitre at 33.5\%) with two fractions (lifting and tillering) was applied.

Data were recorded for 6 qualitative characters using Durum Wheat Descriptors IBPGR (International Board for Plant Genetic Resources) (Table 1).

Phenotypic frequency distributions of the characters were worked out for all the materials.

TABLE 1. Qualitatively measured traits

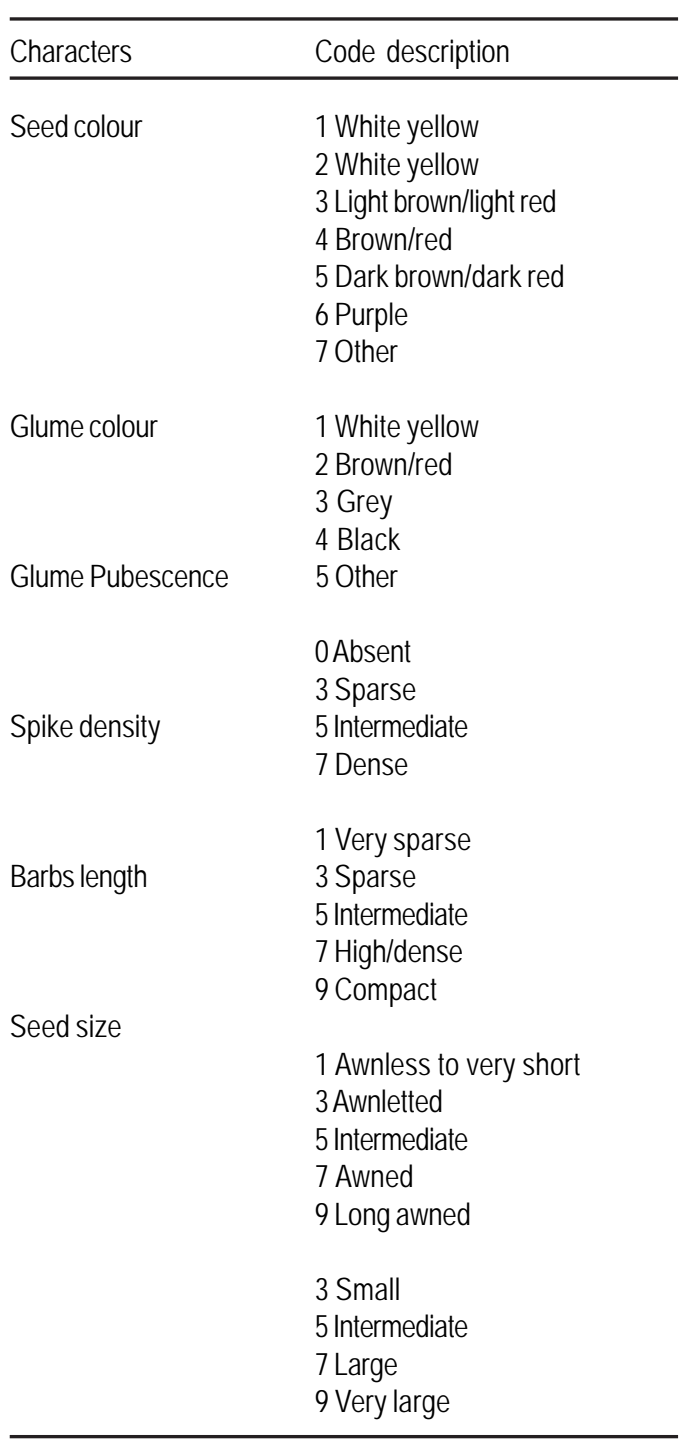


The Shannon-Weaver diversity index (H') was computed using the phenotypic frequencies to assess the phenotypic diversity for each character. The Shannon- Weaver diversity index as described by Hutchenson (1970) is given as:

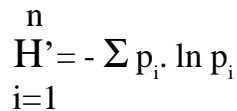

Where pi is the proportion of accessions in the $\mathrm{i}^{\text {th }}$ class of an n-class character and $n$ is the number of phenotypic classes for a character. Each value of H' was divided by its maximum value, $\log n$, and normalised in order to keep the values between zero and one.

\section{RESULTS AND DISCUSSION}

The distribution of six studied characters is presented in Figure 1. Most accessions showed white $(61 \%)$ or brown (27\%) glume (Fig. 2). Generally, the accessions with black glumes are rare (Tesfaye et al., 1991).

Moreover, $58 \%$ of accessions showed glabre glume and $27 \%$ had an important glume pubescence (Fig. 3). Hairiness is a monogenically inherited dominant trait (Mcintosh, 1988), and yet its frequency is lower than the recessive allele, suggesting the presence of a selection disadvantage linked to this gene. Although the adaptive significance of glume hairiness is not clearly known, its association with resistance to kernal bunt (Tilletia indica) (Warham, 1988) and powdery mildew (Erysiphe graminis) (Negassa, 1986), has been reported.

Most of the accessions presented long (49.5\%) or intermediate barbs (42.3\%). Several authors showed a significant correlation between the presence of the barbs and yield grain of durum wheat (Chhabra and Sethi, 1989; Dali et al., 2003). Indeed, the elimination of the barbs during the emergence phases of spike and the anthesis resulted in a reduction of the yield into grain of 17.31 and $13.49 \%$, respectively.

Moreover, $40 \%$ of accessions had an important seed size and 37\% with intermediate size. The most abundant glume colours in this collection were brown (40\%) and yellow white (29\%) (Fig. 4).
Most accessions had high (40\%) and intermediate (45\%) spike density. Sapegin and Baransky (1922) noted that a compact spike showed resistance to brown rust. The trait is controlled by two nonallelic recessive genes named sc 1 and sc 2 (Goncharov, 1997). Gene sc 1 is responsible for semicompactoid spike and, when complemented by gene sc 2, it forms a compactoid spike in tetraploid wheat. This finding colaborated the suggestions of Daaloul et al. (1998) that density spike is more important in relatively cool and wet regions.

The estimates of the Shannon-Weaver diversity index, $H^{\prime}$ for the six characters are presented in Table 2 . For all accessions, the value of H' varied from 0.69 for size seed to 0.86 for spike density. All parameters presented diversity indices higher than 0.60, which showed a large diversity on each parameter. Moreover, this durum wheat germoplasm presented a diversity index about 0.77 , showing a relatively important phenotypic diversity of this collection.

A similar study based on 21 morphological and development traits for 132 accessions showed that Jordanie presented a phenotypic diversity index about 0.67 (Jaradat et al., 1992). Moreover, Bechere et al. (1996) estimated phenotypic index for Ethiopian germoplasm formed by 24 durum wheat populations at 0.70 . The best indices are observed for seed colour $\left(H^{\prime}=0.99\right)$, size grain $\left(H^{\prime}=0.96\right)$ and glume pubescence $\left(\mathrm{H}^{\prime}=0.88\right)$. The weakest index was noted for spike density $\left(H^{\prime}=0.24\right)$. In this study, this trait presented the best index $\left(\mathrm{H}^{\prime}=0.86\right)$. These values showed that this germoplasm presented a large diversity, which confirmed that Tunisia is one of the principal durum wheat secondary centres of diversification. This genetic diversity can be exploited in improvement programmes.

TABLE 2. Index diversity ( $\left.\mathrm{H}^{\prime}\right)$ of each trait

\begin{tabular}{ll}
\hline Measured traits & $\mathrm{H}^{\prime}$ \\
\hline Seed colour & 0.71 \\
Seed size & 0.69 \\
Glume colour & 0.79 \\
glume pubescence & 0.8 \\
Spike density & 0.86 \\
Barb length & 0.77 \\
\hline
\end{tabular}


a
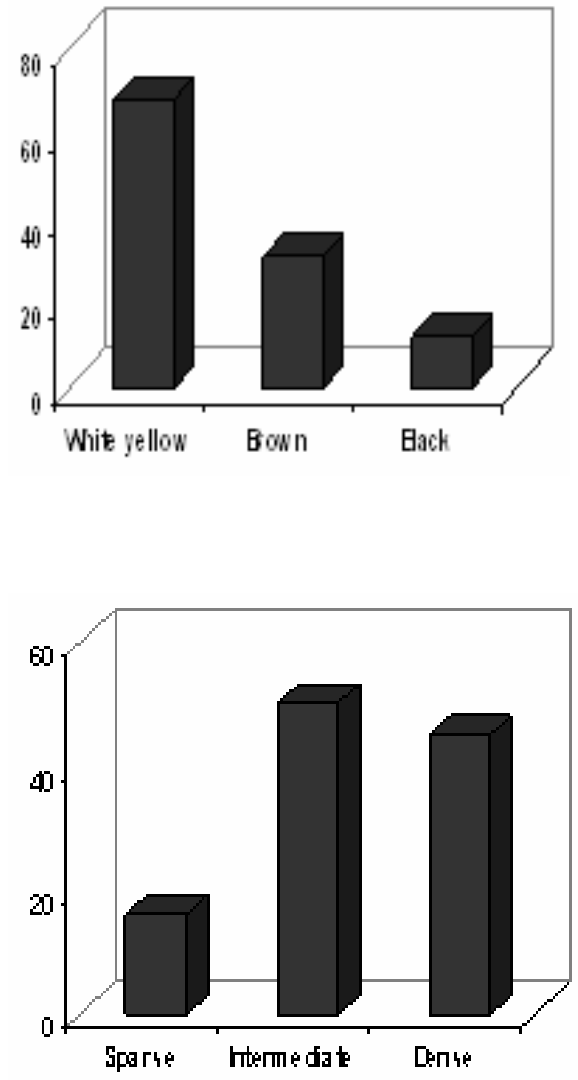

e

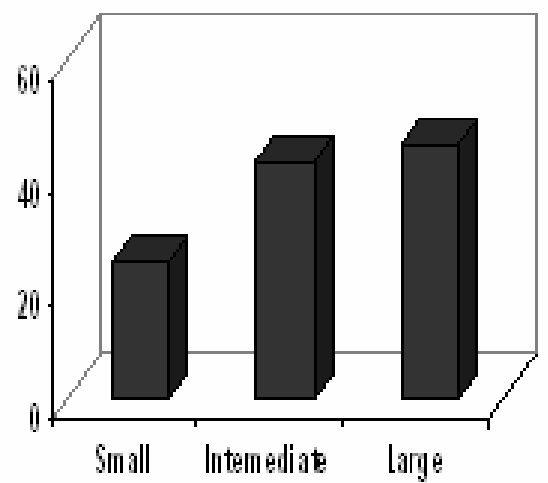

b

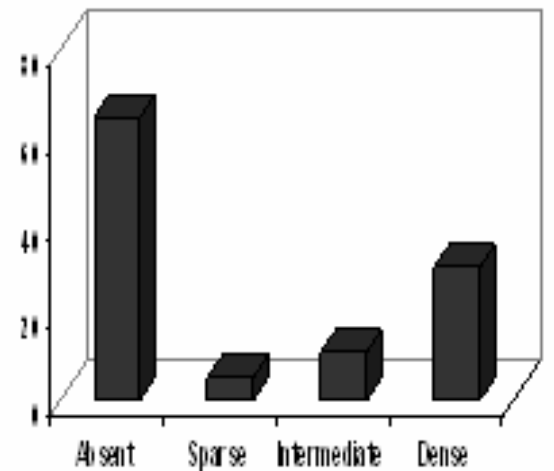

d

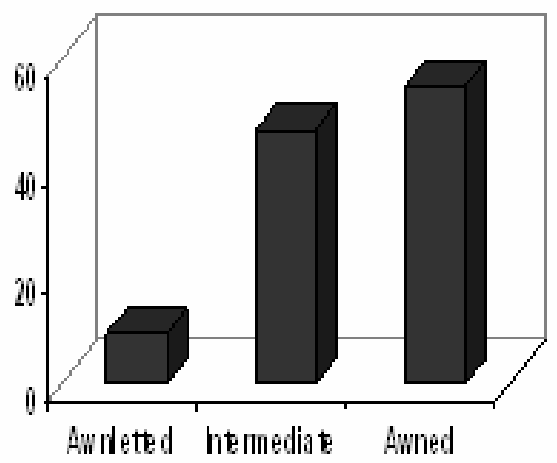

f

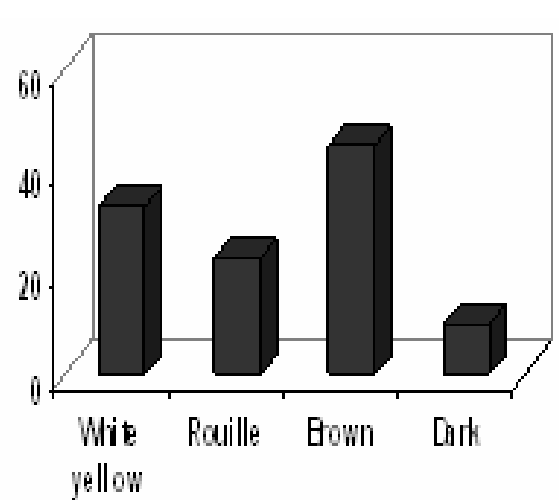

Figure 1. Frequencies distribution of 111 accessions according to glume colour (a), pubescence of glume (b), spike density(c), barb length (d), size (e) and colour (f) grain in a study in Tunisia. 


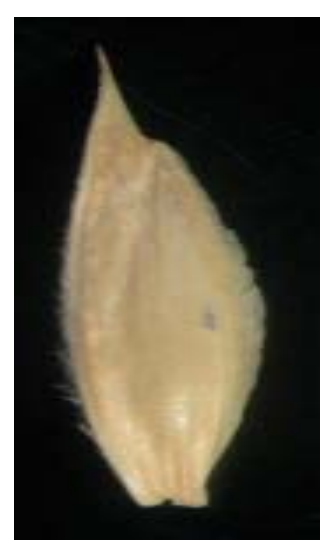

A

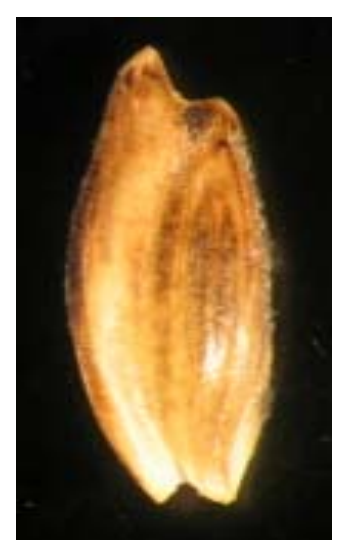

B

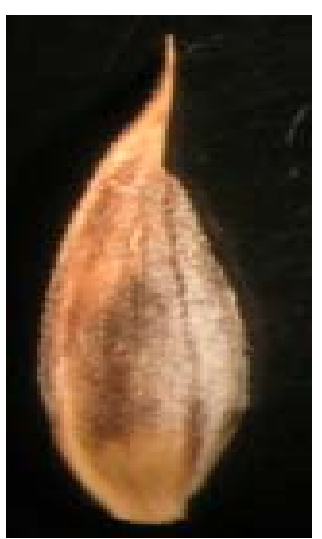

C

Figure 2. Variation of glume colour (A: Glume White yellow, B: Glume Brown, C: Glume dark)

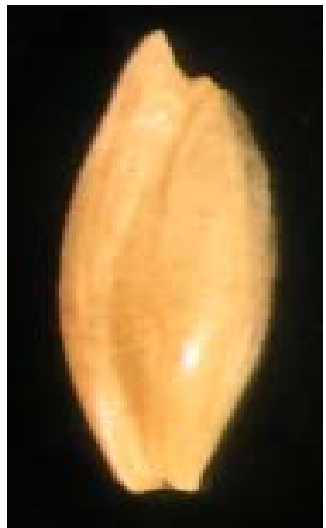

A

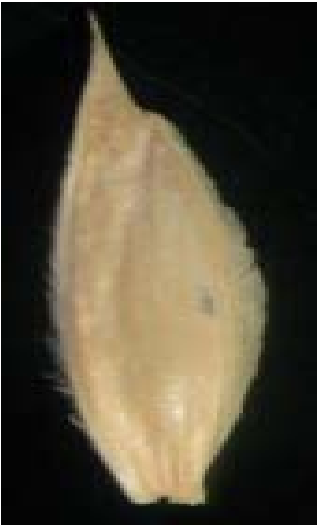

B

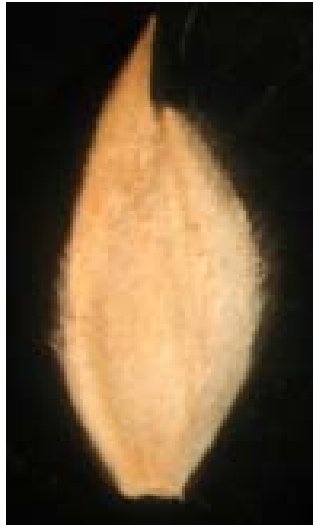

C

Figure 3. Different pubescence degree of glume (A: sparse, B: intermediate, C: dense).

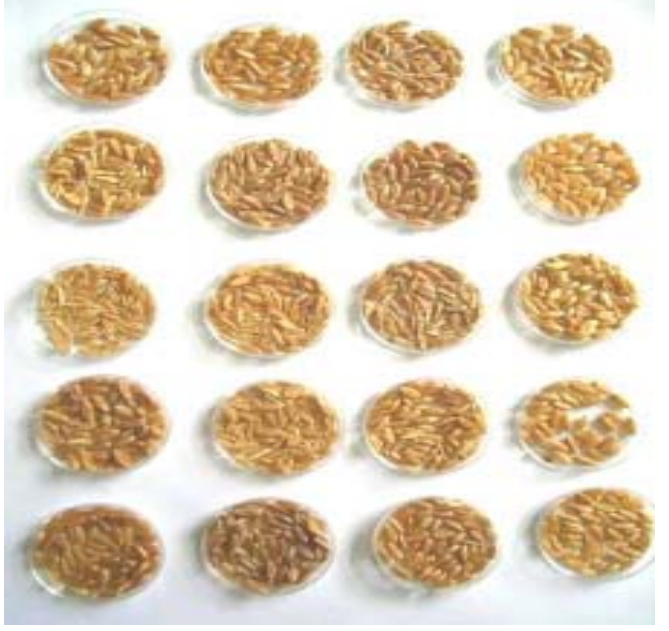

Figure 4. Different seed colour of durum wheat. 


\section{CONCLUSION}

Tunisian durum wheat germoplasm presented a diversity index about 0.77 showing a relatively important phenotypic diversity of this collection. The high diversity observed showed that Tunisia is one of the centres of diversity of durum wheat. This genetic diversity can be exploited in improvement programmes.

\section{REFERENCES}

Bechere, E., Belay, G., Mitiku, D. and Merker, A. 1996. Phenotypic diversity of tetraploid wheat landraces from northern and north-central regions of Ethiopia. Hereditas 124: 165-1 72.

Chhabra, A.K. and Sethi, S.K. 1989. Contribution and association of awns and flag-leaf with yield and its composants in durum wheat. Cereal Res.Commun. 17: 265-271.

Daaloul, A., Harrabi, M., Amara, H. and Gougjil, S. 1998. Evaluation de la collection nationale de blé dur. Revue de l'Institut national Agronomique de Tunisie, numéro spécial 0330-8065: 337-358.

Devra, I., Javies and Hodgkin, T. 1999. Wild relatives and crop cultivars: detecting natural introgression and farmer selection of new genetic combinations in agroecosystems. Molecular Ecology 8:159-173.

Fakhfak, M., Daaloul, A., Rezgui, S. and Yahyaoui, A. 1998. Evaluation des associations entre le rendement en grain et les caractères morphophysiologiques chez le blé dur dans les régions semi-arides. Revue de l'Institut national Agronomique de Tunisie 13(2): 4351.

Goncharov, N.P. 1997. Comparative genetic study of tetraploid forms of common wheat without D genome . Russian J. Genetic. 33: 549-552.

Holubec, V., Hanusova, R. et Kostkanova, E. 1992. The Aegilops collection in the Praha-Ruzyng
(Czechoslovakia) Gene Bank: collecting, evaluation and documentation. Hereditas 116: $271-274$.

Hutcheson, K. 1970. A test for comparing diversities based on the Shannon formula. $J$. Theor. Biol. 29: 151 -154.

IBPGR, 1985. Descriptors for wheat. International Board for Plant Genetic Resources, Rome, Italy.

Jaradat, A.A. 1992. Breeding potential of durum wheat landraces from Jordan. Hereditas 116:301-304.

Khereddine, N. et Daaloul, A. 1998. Etude des potentialités génétiques de rendement en grain et des composantes de rendement et leur relation chez quinze variétés de blé dur en Tunisie. Revue de l'Institut national Agronomique de Tunisie 13: 33-48.

Mcintosh, R. 1988. A Catalogue of gene symbols for wheat. In: Proceedings of the Seventh International Wheat Generics Symposium. T. E. Miller, C.R. and Koebner, R. M. D. (Eds.), pp. 1225-1323. Cambridge.

Negassa, M. 1986. Estimates of phenotypic diversity and breeding potential of Ethiopian wheats. Hereditas 104: 41-48.

Porfiri, O., Torricelli, R., Silveri, D. D., Papa, R., Barcaccia, G. and Negri, V. 2001. The Triticeae genetic resources of central Italy: Collection, evaluation and conservation. Hereditas 135: 187-192.

Sapegin, A.A. and Baransky, D.I. 1922. hybridological analysis of correlated wheat traits. II. Proc. Odessa Agric. Plant Breeding Station 7: 19-26.

Tesfaye, T., Getachew, B. and Worede, M. 1991. Morphological diversity in tetraploid wheat landrace populations from the central highlands of Ethiopia. Hereditas 114:171-176.

Warham, E. J. 1988. Screening for karnal bunt (Tillrriu indica) resistance in wheat, Triticale, rye and barley. Can. J. Planf.Pathul. 10:5760. 